\title{
ОСОБЕННОСТИ МИНЕРАЛОВ СЛЮД В КИМБЕРЛИТАХ
}

\author{
Н. Н. Зинчук \\ Западно-Якутский научный центр (ЗЯНЦ) АН РС (Я), г. Мирный
}

Поступила в редакцию 12 декабря 2017 г.

\begin{abstract}
Аннотация: изверженные и осадочные породы, а также их метаморфические разности, слагающие континентальные блоки земной коры, в процессе гипергенеза и литогенеза возникающих в этих случаях продуктов, претерпевают закономерные специфические изменения, зависящие от петрохимических и генетических особенностей исходных пород. Продукты выветривания бесслюдистых разностей изверженных пород, а также осадочных (как бесслюдистых, так и слюдистых) разностей, вследствие весьма мелкого размера частии первичных и вторичных минералов следует изучать во фракиии мельче 0,001 мм. В отличие от этого, в слюдистых разностях изверженных пород, благодаря в основном более крупному размеру слюдистых частии, объективные данные об их гипергенном изменении могут быть получены лишь при комплексном изучении как фракиии мельче 0,001 мм, так и породы в целом. При этом присутствие в метаморфизованных породах слюдистых минералов типа серицита (то есть дисперсного мусковита) указывает на необратимый процесс изменения поступающего с суши обломочного материала даже на наиболее поздних стадиях литогенеза. Особое внимание уделено изучению образующихся в постмагматическую стадию минералов-новообразований кимберлитовых пород, установленные типоморфные особенности отдельных из которых можно успешно использовать при поисках алмазных месторождений. На основании комплексного исследования акцессорных и породообразующчих минералов кимберлитов трубок прослежены процессы вторичного минералообразования. Изучены продукты изменения кимберлитовых пород, составлена схема преобразования исходных минералов. В переотложенных продуктах выветривания можно дифференцировать на структурном уровне одни и те же разновидности минералов, а также идентифицировать вторичные слоистые силикаты, различающчиеся либо характером заселения октаэдрических позиций в их структуре, либо способом взаимного наложения отдельных силикатных слоев или их политипией. Переотложенные в древних осадочных толщах продукты различных типов слоистых силикатов сохраняют структурные и кристаллохимические особенности по отношению к минералам элювиальных толщ, что позволяет проследить пути поступления в бассейны седиментации терригенного (в том числе и алмазоносного) материала.
\end{abstract}

Ключевые слова: гипогенные и гипергенные минералы, типоморфизм минералов, алмазоносные толщии.

\section{FEATURES OF MICACEOUS FORMATIONS IN KIMBERLITE}

Abstract: eruptive and sedimentary rocks, as well as metamorphic differences of the latter, composing continental blocks of the Earth crust during hypergenesis and lithogenesis of arising in these cases products, suffer natural specific changes (alterations) depending on petrochemical and genetic features of initial rocks. Products of weathering of non-micaceous differences of erupted rocks, as well as sedimentary (both non-micaceous and micaceous) differences, owing to rather fine particle size of primary and secondary minerals should be studied in smaller than $0.001 \mathrm{~mm}$ fraction. As opposed to this, objective evidence about hypergene alteration in micaceous differences of erupted rocks, mainly due to larger size of micaceous particles, can be received only during complex research of both smaller than $0.001 \mathrm{~mm}$ fraction and of the rock in whole. The presence of micaceous minerals of sericite type (that is disperse muscovite) in metamorphosed rocks at this points to an irreversible alteration process of the coming from dry land detritus even at the latest stages of lithogenesis. Special attention is paid to the study of mineralsneoformations of kimberlite rocks, formed at postmagmatic stage, the specified typomorphic features of some of which can be successfully used during prospecting of diamond deposits. Basing on complex research of accessory and rock-forming minerals of kimberlite rocks the processes of secondary mineral formation have been followed in details. The products of kimberlite rocks alteration have been researched; the scheme of initial minerals transformation has been constructed. Redeposition of products of 
weathering of various composition rocks near denudation areas and accumulation mainly in freshwater basins, as well as small thickness of the formed sedimentary layers and their insignificant immersion determined weak hydrodynamic impact of environment on allothigenic minerals (argillaceous, first of all), which has not led to sufficient diagenetic alteration. That is why redeposited in ancient sedimentary thick layers products of various types of crusts of weathering preserve structural and chrystallochemical features in relation to the minerals of eluvial thicknesses, which allow tracing the ways of terrigenous material arrival into sedimentation basins (including diamondiferous material).

Key words: hypogene and hypergene minerals, typomorphism of minerals, diamondiferous thicknesses.

Кимберлитовые породы - сложная гетерогенная система, состоящая из различных пропорций мантийного и корового вещества. Мантийный материал представлен ассоциацией глубинных минералов и ксенолитов пород мантии, сцементированных мезостазисом. Коровую составляющую образуют ксенозерна и ксенолиты вмещающих пород, а также переотложенный от них растворенный материал. Слюдяными (щелочными) кимберлитами обычно называют породы, содержащие более $5 \% \mathrm{~K}_{2} \mathrm{O}$, который входит преимущественно в состав флогопита. Щелочность кимберлитов обратно пропорциональна их титанистости и возрастает от менее глубинных популяций к более глубинным [1-2]. Ранее В. Б. Василенко с соавторами [3] рассмотрены основные свойства слюдяных кимберлитовых пород Сибирской платформы (СП), включающие: а) типизацию по содержанию $\mathrm{K}_{2} \mathrm{O}$; б) распределение пород различной щелочности в кимберлитовых полях; в) распределение пород разной щелочности в диатремах продуктивных кимберлитов; г) анализ причин, определяющих возникновение кимберлитов разной щелочности; д) алмазоносность кимберлитов разной щелочности. Выделение типов щелочных пород исследователями проведено по различным кимберлитовым полям СП, что позволило достоверно выделить четыре типа щелочных кимберлитов: ультраосновной, слюдистый, сублампрофировый и лампрофировый. Ультраосновной (базальтоидный) тип с модой $0,4 \% \mathrm{~K}_{2} \mathrm{O}$ отличается от остальных минимумом при значении 0,75 \% этого оксида. Это касается и слюдистых кимберлитов, которым соответствует максимум в границах $0,75-1,17 \% \mathrm{~K}_{2} \mathrm{O}$. К сублампрофировому типу отнесены разновидности щелочных пород, лежащие в пределах 1,2-2,2 \%, а к лампрофировому - все составы с $\mathrm{K}_{2} \mathrm{O} 2,2 \%$. Однако нами [3-4] рекомендовано для отличия кимберлитов от щелочных пикритов и других видов пород использовать граничные значения $\mathrm{TiO}_{2} 2,5 \%$ и $\sum \mathrm{Fe}<10 \%$. Алмазоносность кимберлитов возрастает по мере падения содержания $\mathrm{TiO}_{2}$ от уровня 2,2\%. Щелочные пикрит-кимберлиты с $\mathrm{TiO}_{2}$ в пределах от 2,2 до 2,8 \% также содержат [5-10] некоторое количество алмазов, резко уменьшающееся в более титанистых разностях. Породы Малоботуобинского (МБАР), Далдыно-Алакитского (ДААР) и Верхнемунского (ВМАР) алмазоносных районов характеризуются преобладанием ультраосновных составов, а в Накынском (НКП) Среднемархинского алмазоносного района (СМАР) и северных кимберлитовых полях превалируют образования со щелочным уклоном [11-15]. В кимберлитовых диатремах СП довольно широко распространены слюдистые образования, среди которых доминируют $[4,8-10]$ флогопит и продукты его изменения, нередко являющиеся породообразующими минералами (рис. 1 и 2). В кимберлитах присутствует три генерации флогопита. Первая обычно представлена вкрапленниками таблитчатой и овальной формы, достигающими 5-7 см. Размеры чешуек слюд первой генерации отличаются в различных диатремах. Флогопиты второй генерации образуют в основной массе кимберлитов две группы мелких пластинчатых и чешуйчатых кристаллов: изометричные идиоморфные псевдогексагональные таблички и удлиненные пластинки. Третья генерация представлена чешуйчатым флогопитом с размерами выделений в несколько миллиметров. Первые две генерации обычно окрашены в коричневый, бурый и зеленовато-бурый цвета, а третья - имеет бурую, желтовато-бурую, золотистую или белесую окраску. Большинству изученных флогопитов из кимберлитов характерна модификация $1 \mathrm{M}$ иногда с примесью 2М 1 . Установлены [5-9] структурные и химические отличия магматогенных флогопитов (низкая степень совершенства структуры и повышенное содержание $\mathrm{Al}^{3+}$ в тетраэдрах) от метасоматических (более высокое совершенство структуры и наличие в октаэдрах $\mathrm{Fe}^{3+}$ ), что обусловлено разными генетическими условиями образования минерала. В постмагматическую стадию изменения кимберлитов флогопит существенно преобразуется (в первую очередь хлоритизируется), что наиболее характерно для МБАР и ДААР. Севернее степень изменения флогопита не столь велика, но и здесь в некоторых диатремах и жилах его значительная часть замещена минералами-новообразованиями, сохраняющими первичную форму исходного флогопита. Чешуйчатые выделения хлоритов из кимберлитовых пород состоят из пакетов типа $\delta$ и $\delta^{\prime}$ [4] и имеют различную степень упорядоченности структуры. Особенно сконцентрированы слюдистые выделения в основной массе кимберлитов, где они нередко являются породообразующими компонентами. Поскольку такие выделения в основной массе очень малы, возникают трудности при их изучении и особенно количественном учете. Для решения последней задачи наиболее приемлем метод пересчета химических анализов на минеральный состав, разработанный раньше [4, 9]. Детально слюдистые образования изучены нами (рис. 1, а-в и 2, а-в) на примере кимберлитовой трубки Удачная в ДААР, где кроме комплексной характеристики рассмотрены особенности их распределения, как по латерали, так и 

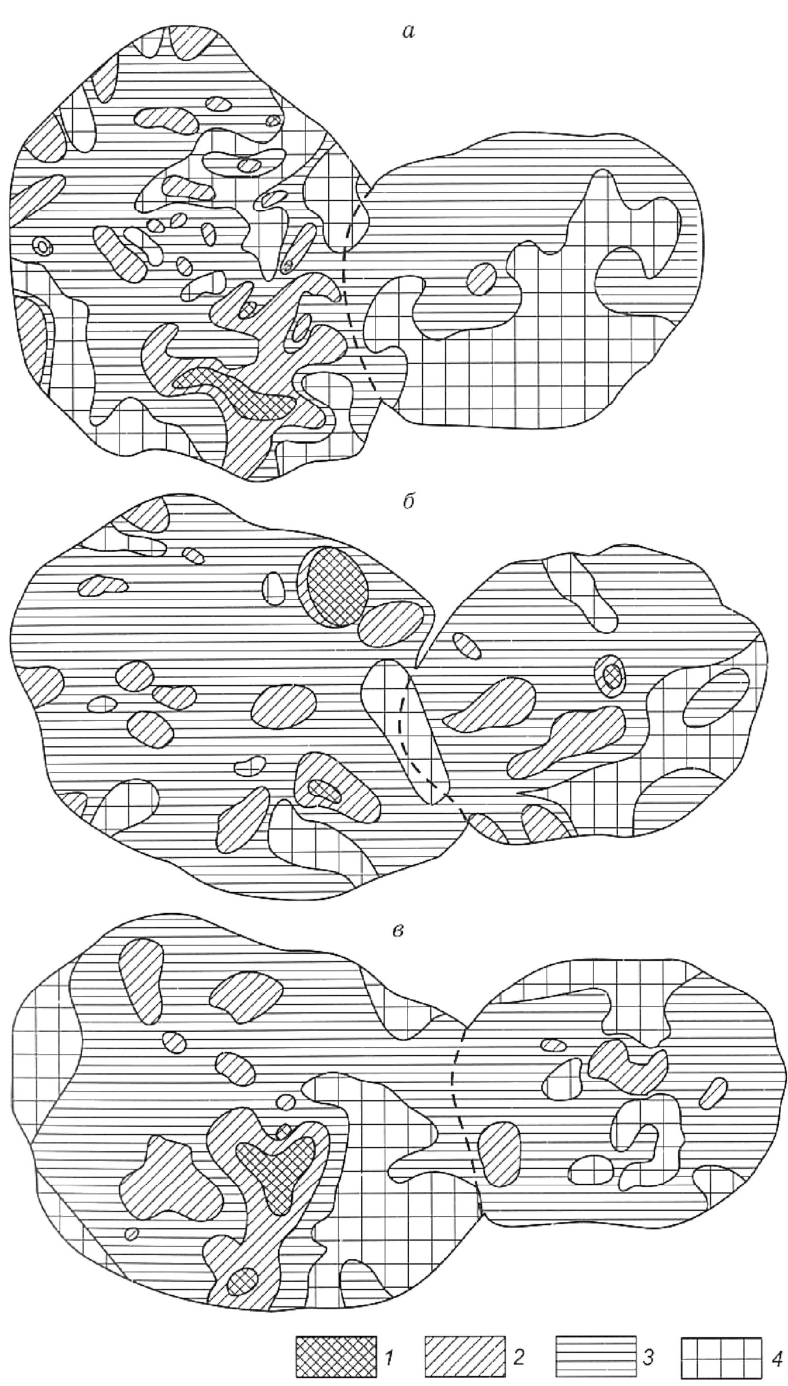

Puc. 1. Схема распределения флогопита в кимберлитах различных опорных горизонтов трубки Удачная: глубина от поверхности трубки (в м): $a-15, \sigma-115$, в - 280; концентрация флогопита (в \%): 1 - >20, 2 - 16-20, 3 - 12-16, $4-8-12,5-4-8,6-0-4$.

на разведанную глубину диатремы (до 1200 м). Закономерности вариации концентрации флогопита и образованного за счет его изменения хлорита изучены по материалам комплексного изучения пяти опорных горизонтов, из которых отобраны образцы по сетке эксплуатационных скважин на расстоянии 40х40 м. Опорные горизонты расположены от дневной поверхности на глубинах (в м): 15 - верхний горизонт (рис. 1, а и 2, а); 55 - средний горизонт (рис.1, б и 2, б) и 115 - нижний горизонт (рис. 1 , в и 2, в). По сути эти опорные горизонты представляют типичный профиль коры выветривания (КВ), отражающий зоны (горизонты): плотных пород (нижний), зоны дезинтеграции (средний), гидролиза и выщелачивания (верхний). Распределение слюдистых образований на разведанную глубину диатремы изучали по керну скважин колонкового бурения.

Кимберлитовая трубка Удачная [2-5, 10-12], состоящая из двух сопряженных тел (восточного и за-
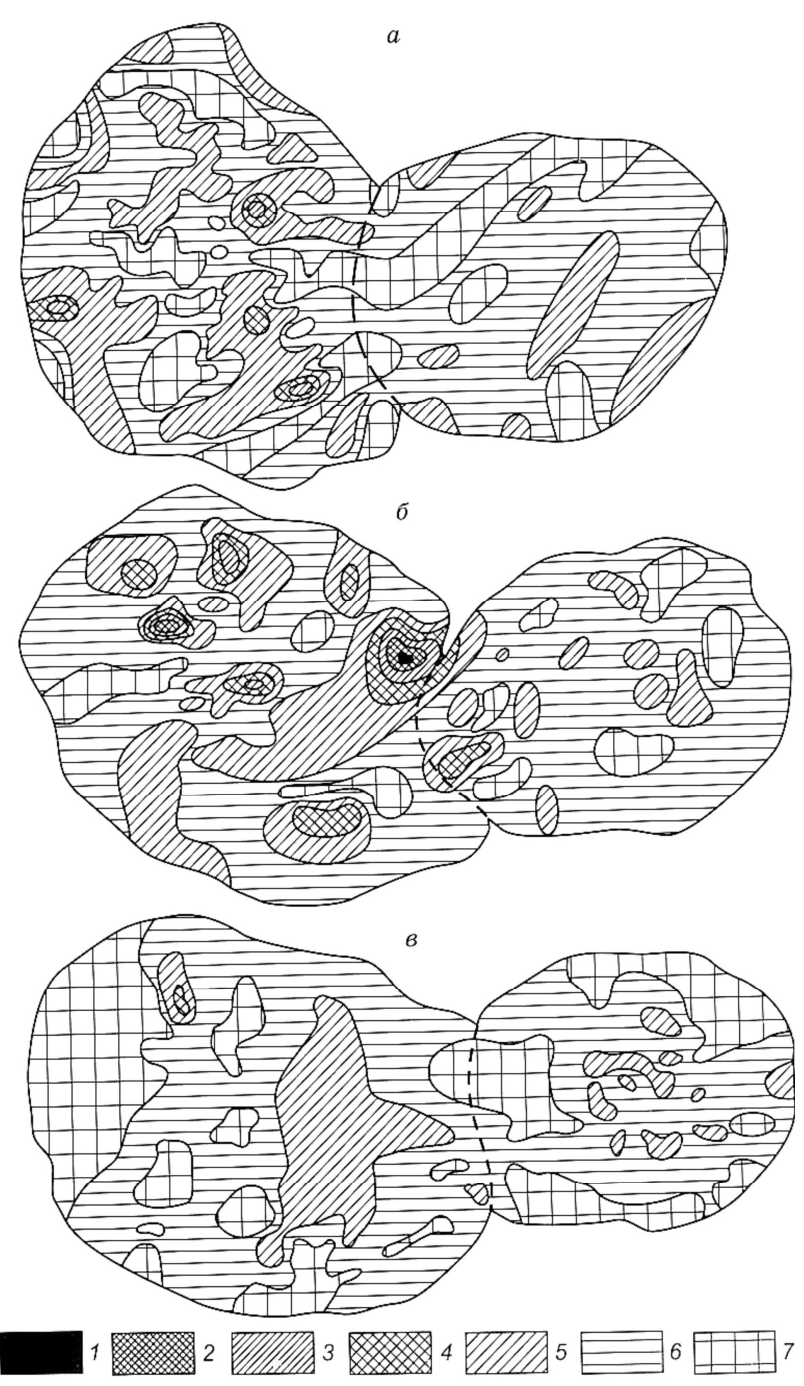

Puc. 2. Схема распределения хлорита в кимберлитах различных опорных горизонтов трубки Удачная: глубина от поверхности (в м): $a-15, \sigma-115$, в - 280; концентрация хлорита (в \%): 1 - 20-25, 2 - 15-20, 3 - 10-15, 4 - 5-10, 5 $0-5$.

падного), на поверхности в плане имеет форму искаженной восьмерки. Западное тело крупнее восточного. В верхней части (примерно до глубины 250-270 м) оба тела либо контактируют (рис. 1, а и 2, а), либо разобщены (рис. 1 , в и 2, в). Вмещающими породами c поверхности являются карбонатные отложения нижнего ордовика, на глубине - среднего и верхнего кембрия. Внутреннее строение обоих тел довольно сложное и неоднозначно интерпретируется различными исследователями [1-3, 7-9, 14-15]. Восточное тело сложено серыми, зеленовато- и темно-серыми кимберлитовыми брекчиями (КБ). Главные породообразующие компоненты - псевдоморфозы по оливину (реже свежий минерал), представленные смесью серпентина и кальцита. Отмечено повышенное (по сравнению с западным телом) содержание ксенолитов глубинных пород и сравнительно пониженное - ксенолитов осадочных пород. В отдельных участках отмечены многочисленные (35-40\%), по сравнению с 


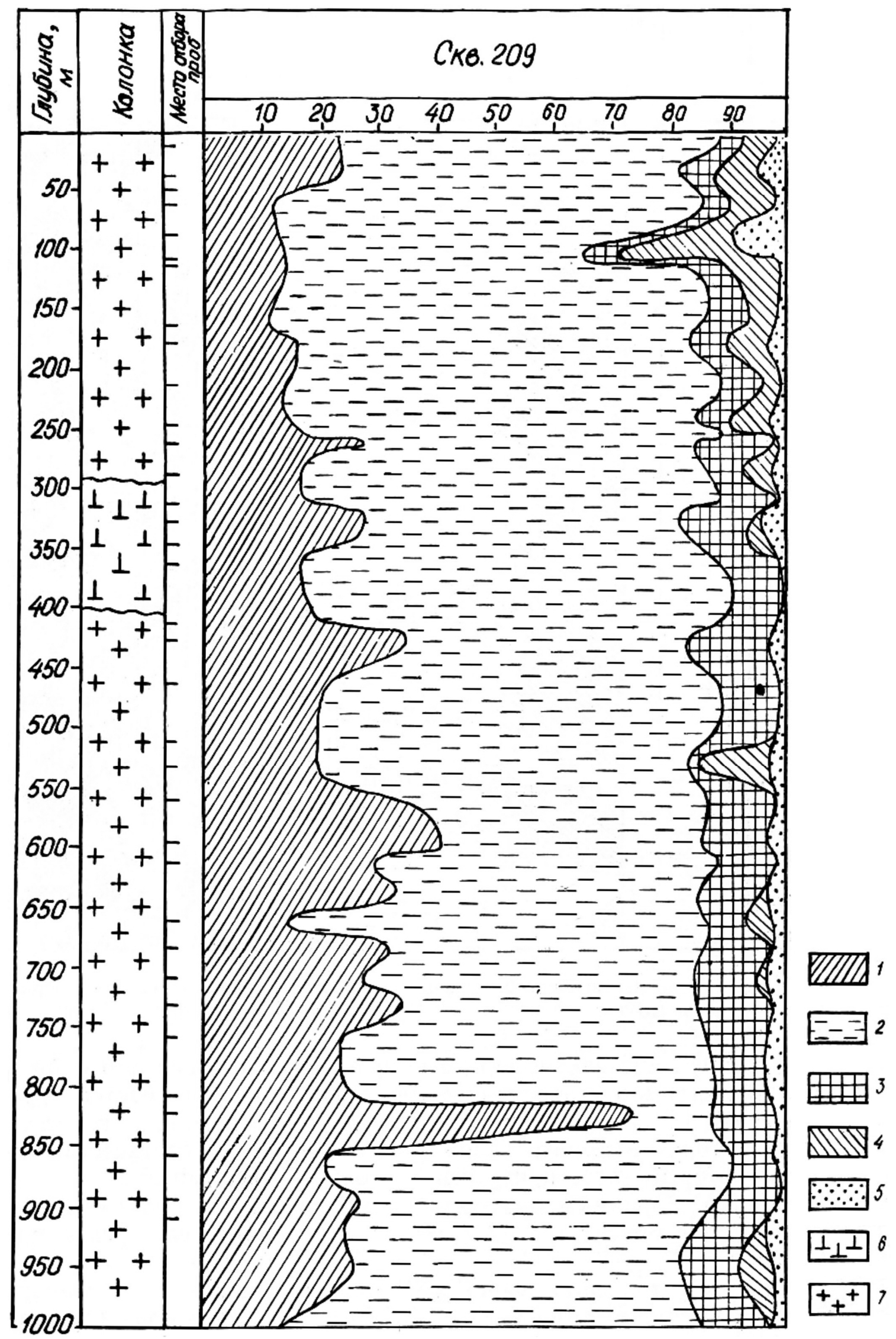

Puc. 3. Распределение преобладающих минералов в основной массе кимберлитовых пород трубки Удачная (по разведочной скважине 209): 1 - кальцит, 2 - оливин+серпентин, 3 - флогопит, 4 - хлорит, 5 - гипс+галит+апатит, 6 - порфировый кимберлит, 7 - кимберлитовая брекчия. 
западным телом, автолиты. Основная масса восточного тела сложена карбонат-серпентиновым агрегатом с мелкими выделениями рудного минерала, перовскита и микролитами кальцита. В отличие от этого, верхние части западного тела выполнены серыми и зеленовато-серыми КБ, интенсивно измененными вторичными процессами. Ксеногенный материал представлен обломками осадочных пород, кристаллических сланцев, реже ультраосновных разностей. Цемент - карбонатсерпентиновый агрегат с мелкими выделениями рудного минерала, измененных слюдистых образований и многочисленными мелкими псевдоморфозами по оливину, замещенными серпентином и карбонатами. Слюдистые образования присутствуют в кимберлитах диатремы практически на всю разведанную глубину (рис. 3). Значительное количество флогопита выявлено при картировании самого глубокого опорного горизонта, где достигает $20 \%$ и более. Для кимберлитов восточного тела отмечено (рис. 1, а-в) постепенное уменьшение вверх по разрезу концентрации флогопита, которое не характерно для западного. Установлена зональность с тенденцией убывания содержания минерала к периферии трубки. На верхнем горизонте диатремы концентрация флогопита редко превышает $5 \%$.

Повышенные концентрации слюдистых минералов отмечены нами также в кимберлитах трубок Нюрбинская и Ботуобинская, находящихся в СМАР СП, расположенных вблизи друг от друга на расстоянии 3 км и приуроченных к Вилюйско-Мархинской зоне разломов северо-восточного простирания [1-3, 9-11, 14 16]. Вмещающие кимберлитовые трубки породы представлены в НКП осадочными образованиями верхнего кембрия мархинской свиты и согласно залегающими на них породами нижнего ордовика олдондинской свиты. Разрез позднекембрийской толщи сложен преимущественно доломитами, в меньшей степени отмечаются известняки. Характерно также наличие тонковолокнистых пестроцветных и красноцветных доломитистых мергелей и аргиллитов. Осадочные образования нижнего ордовика относятся к комплексу биогенных, хемогенных и терригенных глинисто-карбонатных отложений шельфовых эпиконтинентальных морей с нормальной соленостью, накапливавшихся в условиях приливно-отливной аридной зоны. Разрезы сложены тремя ассоциациями литогенетических типов, характерных для дна мелководной равнины: волнисто- и горизонтально-слоистыми известковистыми или доломитистыми мергелями, глинистыми доломитами выровненных понижений; разнообразными известняками пологих возвышенных частей; волнисто-слоистыми аргиллитами центральных застойных частей понижений. Все литогенетические типы и их ассоциации ритмично переслаиваются, слагая пачки, пласты, слои и прослойки, что свидетельствует о существовании значительных фациальных переходов.

Перекрывающие кимберлитовые трубки породы представлены [17- 21] нижнеюрскими терригеннокарбонатными образованиями мощностью до 70 м.
Они сложены песками, слабо литифицированными песчаниками, аргиллитами и алевролитами с линзами и прослойками известняков. В нижней части толщи прослеживается маломощный горизонт выполненный гравелитами. Последние состоят из отсортированных обломков выветрелых карбонатных пород, сцементированных глинисто-песчанистым материалом. В структуре кимберлитовой трубки Ботуобинская выделяются [22-25] все элементы строения таковой: подводящий канал (дайкообразное тело), диатрема и кратер. Все встреченные типы пород в данной трубке можно разделить на следующие фации кимберлитового магматизма: породы гипабисальной (субвулканической) фации представлены порфировыми кимберлитами (ПК), к жерловой отнесены автолитовые кимберлитовые брекчии (АКБ), кратерная фация выполнена кимберлитовыми туфобрекчиями (КТБ). Порфировые кимберлиты образуют дайкообразное тело северо-восточного простирания. Макроскопически - это породы зеленого, голубовато-серого цвета различной тональности, средней крепости и плотности. Структура их средне-крупнопорфировая, текстура массивная. Содержание ксеногенного материала варьирует в пределах 5-7 \% от объема породы, преобладают обломки пород кристаллического фундамента (гнейсы, кристаллические сланцы). Основная масса сложена зеленовато-серым мелко-тонкозернистым агрегатом серпентина. Порфировые выделения представлены псевдоморфозами серпентин-карбоната по оливину I и II генерации, по содержанию вторые преобладают, а также лейстами хлоритизированного флогопита и редкими зернами пиропа и пикроильменита. АКБ характеризуются максимальным распространением. Структура пород порфировая, текстура брекчиевая. Обломочный материал представлен, в основном, обломками вмещающих пород нижнего палеозоя, реже встречаются породы кристаллического фундамента. Отмечаются единичные обломки ПК ранней фазы внедрения. Связующая масса брекчий характеризуется мелкозернистым строением и гетерогенным составом. В верхних горизонтах преобладает кальцит, хлорит и глинистые образования. С глубиной увеличивается доля серпентина и появляются лейсты флогопита. Среди индикаторных минералов кимберлитов (ИМК) встречаются зерна пиропа и хромшпинелидов, а также единичные зерна пикроильменита. В целом содержание тяжелых минералов в АКБ, так же как и в ПК, очень низкое. Автолиты представлены округлыми, изометричными или эллипсоидными обособлениями с концентрической зональностью. Широко распространены автолиты ядерного типа, ядрами которых служат псевдоморфозы по оливину или обломки ксеногенного материала. КТБ кратерной фации имеют распространение в северо-восточной части трубки и прослеживаются до глубины 250 м. Данные породы являются производными АКБ, для них характерно повышенное содержание (до 70 \%) ксеногенного материала в виде обломков вмещающих пород. Текстура брекчиевая, структура литокристаллокластическая, 
псефитовая. Цементирующая масса брекчий гибридная, наряду с кимберлитовым материалом отмечается примесь глинистого и терригенного компонента за счет дезинтеграции ксенолитов.

Трубка Нюрбинская эродирована на уровне диатремовой части и представлена лишь двумя морфологическими элементами - дайкой и диатремой. Вся диатрема полностью сложена АКБ и характеризуется повышенным содержанием ксенолитов метаморфических пород фундамента. Ксенолиты осадочных отложений содержатся в меньшем количестве. Отмечаются единичные включения мантийных пород. Связующая масса представлена тонко-мелкозернистым глинисто-карбонатным агрегатом. Автолитовая текстура цемента в верхних горизонтах брекчий проявлена не четко, но с глубиной она приобретает более выраженный характер. Автолиты имеют ядерное строение и состоят из ядра (псевдоморфозы по оливину или обломки ксенолитов) и концентрически-зональной оболочки. Размер автолитов находится в прямой зависимости от размера ядра. Помимо автолитов в северовосточной части трубки фиксируется ксеногенный материал в виде многочисленных обломков слюдистых ПК. Верхние горизонты обеих трубок в определенной степени затронуты гипергенными процессами.

Породообразующие минералы, возникновение которых происходило в постмагматическую стадию становления кимберлитовых диатрем и в процессе их выветривания, относятся к карбонатам и силикатам. По отношению к процессам выветривания их можно разделить на исходные (материнские) и новообразованные (инфильтрационные). В первую группу входят все минералы материнской породы, независимо от их генезиса, т.е. минералы, возникшие до начала выветривания (первичные и вторичные минералы кимберлитов, а также ксенолиты). Среди силикатов к исходным минералам относятся слюды и образовавшийся по ним хлорит, частично кварц, серпентин и тальк, а также, относящиеся сугубо к ксенолитам, полевые шпаты. К новообразованным минералам, которые определяют характер коры выветривания (КВ), относятся силикаты, представленные смектитом и каолинитом, а также большинство пелитоморфного кварца и халцедон. Среди экзогенных образований отмечаются гидроксиды железа и сидерит, последний возник в процессе инфильтрации поверхностных растворов.

Анализ минерального состав КВ кимберлитовых трубок Нюрбинская и Ботуобинская показывает [4, 16-26] ряд общих закономерностей в ее развитии. Прежде всего, отмечается общность исходных вторичных образований, возникших еще до начала выветривания. Для обеих трубок свойственно обогащение отдельных участков дисептохлоритом, содержание которого по разрезам скважин является сравнительно постоянным и исчисляется десятками процентов. Вместе с тем, слюда в КВ кимберлитов фиксируется довольно редко и содержится в небольших количествах, зато встречается тальк. Серпентин в обоих кимберлитовых телах прослеживается только в ниж- ней части КВ и содержится в сравнительно небольшом количестве. Среди карбонатов встречаются кальцит и доломит, содержание последнего в КВ обеих диатрем несколько повышенное. Кроме этих минералов, которые являются вторичными по отношению к исходному оливиновому кимберлиту, в КВ содержатся полевые шпаты, вынесенные из фундамента и не успевшие разрушиться в процессе выветривания и предшествующего ему гидротермального изменения. Породы обоих трубок также обогащены вторичным мелкозернистым (до пелитоморфного) кварцем. Обычно он ассоциирует со смектитом или каолинитом, содержание которых довольно значительное и не сопровождается интенсивным обохриванием. Сидерит в КВ образует систему прожилков, а также встречается в виде выделений, что свидетельствует о его гипергенном происхождении. Перечисленные особенности состава КВ двух кимберлитовых трубок указывают на сходность постмагматических преобразований пород этих тел и условий их выветривания. Сложность строения профиля КВ кимберлитов заключается в том, что, в отличие от кристаллических массивов, породы которых более менее однородны, в случае трубок взрыва имеем дело с различными по происхождению брекчиями, сложенными различными образованиями. Брекчии возникают на разных этапах формирования кимберлитовой трубки: в процессе продвижения кимберлитовой магмы к поверхности они сложены кимберлитом (автолитовые брекчии) мантийным материалом и обломками вмещающих пород; брекчии, образовавшиеся в процессе сноса обломочного материала в кратере после взрыва (делювий); образовавшиеся в процессе начального (физического) выветривания, выполняющего трубку материала (зона крупной дресвы), представляющую собой сцементированный вторичными продуктами элювий. В связи со взрывом, который обычно проходит на пересечении глубинных разломов, а также возникновением дополнительных, не заполненных кимберлитовой магмой трещин и возникновения брекчий, образовавшаяся по этим довольно пестрым по составу породам КВ лишена обычной для площадного типа зональности. Она не может полностью отвечать и линейному типу однородных пород. Кроме того, на древние КВ нанесли свой отпечаток более поздние до современных процессов включительно, что в значительной степени изменило первоначальный их вид. В различной степени претерпевают изменения породы трубки под воздействием глубинных эксгаляций, которые достоверно фиксируются появлением боратов.

Анализируя профиль КВ трубок Нюрбинская и Ботуобинская, можно восстановить эволюцию таковой, которая нам представляется следующим образом. Под влиянием кислородсодержащих осадков сначала по кимберлитам образовалась смектитовая зона и, поскольку дождевые воды богаты кислородом, образовался смектит с окисным железом (нонтронит в случае выветривания серпентиновых кимберлитов и монтмориллонит-нонтронит при изменении хлорити- 
зированных лампрофировых разновидностей, а также богатых ксенолитами пород фундамента). В дальнейшем произошла каолинизация под воздействием углекислоты, выделявшейся в процессе разложения углекислых остатков. Каолинизация в этих же условиях могла проходить также непосредственно по хлоритам, вермикулитам или непосредственно по флогопиту. Окисное железо в процессе каолинизации органическими кислотами экстрагируется в смектитах и других минералах, образуя комплексный анион, который окисляется кислородом воздуха с возникновением гидроокислов железа. Окисное железо восстанавливается в процессе окисления углерода углистых остатков согласно следующей схематической реакции: $4 \mathrm{Fe}^{3+}(\mathrm{OH})_{3}+8 \mathrm{O}_{2}+9 \mathrm{C}_{\text {орг }} \rightarrow 4 \mathrm{Fe}^{2+}\left(\mathrm{HCO}_{3}\right)_{2}+2 \mathrm{H}_{2} \mathrm{O}+\mathrm{CO}_{2}$.

Повышенное выделение $\mathrm{CO}_{2}$ стабилизирует бикарбонатный ион, в связи с которым закисное железо может мигрировать, тем более что соли $\mathrm{Fe}^{2+}$ подвергаются гидролизу при более высоком $\mathrm{pH}$, чем окисного. Бикарбонат при падении парциального давления $\mathrm{CO}_{2}$ распадается с образованием сидерита $\mathrm{Fe}\left(\mathrm{HCO}_{3}\right)_{2} \rightarrow \mathrm{FeCO}_{3}+\mathrm{H}_{2} \mathrm{O}+2 \mathrm{CO}_{2}$, или, попадая в зону аэрации, окисляясь, подвергается дальнейшему гидролизу: $2 \mathrm{Fe}\left(\mathrm{HCO}_{3}\right)_{2}+\mathrm{O}_{2}+\mathrm{H}_{2} \mathrm{O} \rightarrow 2 \mathrm{Fe}(\mathrm{OH})_{3}+4 \mathrm{CO}_{2}$.

Для построения схемы процесса выветривания кимберлитовых пород НКП, взято за основу размещение по вертикали породообразующих минералов по разрезам, пройденным в различных частях трубок Нюрбинская и Ботуобинская. В процессе выветривания возникают продукты, которые отвечают данной физико-химической обстановке, с изменением которой они могут быть некоторое время стабильными (изменяются медленно) или сразу же растворяются, превращаются в другие соединения. С целью выяснения динамики формирования КВ данных кимберлитовых трубок, некоторые минералы этих классов рассмотрены более детально. Как уже отмечалось, главным карбонатным минералом является кальцит, образование которого происходит на всех стадиях формирования и становления кимберлитовых тел. Его присутствие в КВ свидетельствует о $\mathrm{pH}$ среды, в которой находились кальцитсодержащие породы. Разрушение кальцита в процессе выветривания пород происходит, главным образом, под воздействием угольной кислоты. Сероводородистая кислота в таких условиях является неустойчивой, вследствие окисления серы превращается в серную кислоту, под воздействием которой кальцит преобразуется в гипс. На разрушение кальцита большое влияние оказывает агрессивная составляющая угольной кислоты, та ее часть, которая расходуется на растворение углекислого кальция по уравнению: $\mathrm{CaCO}_{3}+\mathrm{H}_{2} \mathrm{O}+\mathrm{CO}_{2} \leftrightarrow \mathrm{Ca}\left(\mathrm{HCO}_{3}\right)_{2}$. Данный процесс обратим и поэтому после полного расходования углекислоты наступает равновесие, а с последующим удалением $\mathrm{CO}_{2}$ реакция может пойти в обратном направлении. Этим объясняется появление кальцита в верхних горизонтах КВ, в то время как в нижних частях кальцит отсутствует. Доломит является более устойчивым к кислотам, чем кальцит, в связи с чем он часто фиксируется в зонах лишенных карбонатов кальция. Доломит в процессе выветривания подвергается гидролизу и бикарбонат кальция ведет себя аналогично таковому, возникшему при разложении кальцита, а бикарбонат магния в дальнейшем обычно входит в октаэдрические позиции слоистых силикатов (смектитов). Образование в КВ сидерита связано с окислительно-восстановительным потенциалом среды (Eh), в зависимости от которого могут возникать окислы (гидроокислы) железа или карбонаты. Сидерит может образовываться даже в слабокислых условиях, при рН раствора равном немного больше пяти, в которых существование кальцита невозможно. Подобные условия в ходе выветривания обеспечиваются наличием в перекрывающих породах органического вещества, окисление которого приводит к предохранению поступившего из исходных пород железа от окисления и содействует образованию карбоната. Угольная кислота оказывает влияние на изменение и возникновение главных силикатных минералов КВ и в первую очередь это касается кандитов. Под ее влиянием на алюминий содержащие минералы также происходит образование каолинита. Создавая кислые условия, углекислота содействует полимеризации находящейся в растворе кремниевой кислоты с образованием кварц-халцедоновых агрегатов. Сонахождение кварца с каолинитом, а также пропорциональное уменьшение в некоторых пробах хлорита и смектита, указывает на то, что источником кремнекислоты явились магнезиально-железистые слоистые силикаты, которые под воздействием углекислых растворов и органических кислот разрушались с удалением магнезии и отчасти железа, а порода обогащалась кварцем. Относительно небольшая часть глинозема исходных минералов в данных условиях связывалась в каолинит.

Магнетит в окислительной среде неустойчивый. Происходит окисление закисного железа с частичным его удалением и образованием маггемита, который не очень стабилен и переходит в стабильный - гематит. В условиях болотного выветривания, магнетит замещается сидеритом, сохраняя реликты (и магнетитные свойства октаэдрических кристаллов) по следующей схематической реакции: $2 \mathrm{Fe}^{2+} \mathrm{Fe}_{2}{ }^{3+} \mathrm{O}_{4}+12 \mathrm{C}_{\text {орг }}+6 \mathrm{H}_{2} \mathrm{O}+$ $11 \mathrm{O}_{2} \rightarrow 6 \mathrm{Fe}\left(\mathrm{HCO}_{3}\right)_{2} \rightarrow 6 \mathrm{FeCO}_{3}+6 \mathrm{CO}_{2}+6 \mathrm{H}_{2} \mathrm{O}$

При этом происходит окисление значительного количества органических остатков и восстановление окисного железа. В условиях гумидного выветривания ильменит и пикроильмениит превращаются в полуразрушенную фазу, из которой выносится часть закисного железа (до $14 \%$ его содержания), частично идет окисление (до $25 \%$ от его содержания). Магний при этом удерживается в структуре ильменита дольше. Подобного рода образования, сохранившие внешнюю форму, цвет ильменита и содержащие, кроме реликтов исходного минерал, а также гематита и анатаза, принято называть аризонитом. В гидротермальных условиях обычно происходит непосредственное замещение ильменита пелитоморфной кристалличе- 
ской фазой, представленной рутилом, анатазом или брукитом. При этом резко меняется цвет агрегата. В процессе экстракции агрессивными водами из аризонита всего железа остается зерно пелитоморфного агрегата светло-коричневого цвета - лейкоксен, состоящий из существовавших уже в аризоните полиморфных разновидностей оксида титана и молекул воды. Пикроильменит часто содержит включения слюды. Нередко он бывает окружен перовскитом. Флогопит в основном замещается 14-ангстремовым хлоритом и встречается только в виде реликтов среди хлоритовых чешуй. Флогопиты магматогенного происхождения характеризуются повышенным содержанием глинозема и поэтому образовавшиеся по ним хлориты содержат алюминий не только в тетраэдрических, но и в октаэдрических позициях с примерно следующей формулой:

$$
\mathrm{Mg}_{4,4} \mathrm{Fe}_{0,3}^{2+} \mathrm{Fe}^{3+}{ }_{0,9} \mathrm{Al}_{0,3}\left[\mathrm{AlSi}_{3} \mathrm{O}_{10}\right] \text {. }
$$

Образовавшийся при повышенных температурах дисептохлорит в ходе выветривания в зависимости от интенсивности прохождения процесса и наличия дополнительных компонентов трансформируется в гидрохлорит по следующих схематических реакциях:

$$
\begin{gathered}
\mathrm{Mg}_{4,4} \mathrm{Fe}_{0,3} \mathrm{Fe}_{0,9} \mathrm{Al}_{0,3}(\mathrm{OH})_{8}\left[\mathrm{AlSi}_{3} \mathrm{O}_{10}\right]+2 \mathrm{H}_{2} \mathrm{O}+\mathrm{CO}_{2} \rightarrow \\
\mathrm{Mg}_{4,2} \mathrm{Fe}_{0,9} \mathrm{Al}_{0,3}(\mathrm{OH})_{4}\left[\mathrm{H}_{2} \mathrm{O}\right]\left[\mathrm{AlSi}_{3} \mathrm{O}_{10}\right]+0,3 \mathrm{Fe}\left(\mathrm{HCO}_{3}\right)_{2}+ \\
0,2 \mathrm{Mg}\left(\mathrm{HCO}_{3}\right)_{2} .
\end{gathered}
$$

Вследствие присоединения протона к оставшимся гидроксилам «бруситовой прокладки» и превращение их, таким образом, в молекулы воды, гидрохлорит трансформируется в смектит. При этом количество тетраэдрического алюминия не уменьшается. Смектит представлен сапонитом, а при наличии достатка глинозема может образоваться бейделит. При интенсивном химическом выветривании под воздействием углекислоты каолинит образуется непосредственно по хлориту (или даже по флогопиту), а промежуточные фазы не возникают.

Гранаты характеризуются наличием различной толщины келифитовой оболочки, возникшей в процессе взаимодействия магматического расплава с образовавшимся пиропом. Они бывают представлены триоктаэдрической слюдой, но чаще образовавшимися по ней вторичными минералами: серпентином и особенно хлоритом. Последний в процессе выветривания изменяется обычным для данного элювия путем, т.е. так же, как и флогопит. Сам же гранат претерпевает изменения, которые не приводят к резкому изменению его физических свойств и заключаются, прежде всего, в экстракции закисного железа, образованием своего рода канальцев с дальнейшим окислением оставшейся его части, т.е. он остается неизмененным.

Оливин в исследуемых трубках замещается, главным образом, серпентином, нередко в сочетании с карбонатами. Вторичные изменения оливина начинаются гидролизом, который для кимберлитовых пород заключается в его серпентинизации с образованием псевдоморфоз, полностью или только в центральной части сложенных лизардитом 1Т. При этом часть же- леза обособляется с образованием магнетита. Другая часть входит в состав лизардита и в магнетит преобразуется только при хризотилизации последнего. Хризотил нередко возникает с лизардитом, когда эти минералы образуют совместно кайму на краю псевдоморфоз, а также вдоль различных трещин в исходном оливине или псевдоморфозе по нему. Магнетита особенно много возникает в процессе серпофитизации, когда образуются его конкреции размером в несколько сантиметров, а сам серпофит сложен хризотилом.

В процессе выветривания минералов группы серпентина, образуется смектит, октаэдрические позиции которого выполнены теми же катионами, что в исходном минерале, только в других соотношениях. Вынос значительного количества магнезии восполняется в некоторой степени окислившимся железом, а также извлечением содержания кремнезема, в результате чего возникает трёхэтажный слой смектита, нехватка положительного заряда которого компенсируется вхождением в октаэдры трехзарядных катионов и в первую очередь окислившегося железа. Поскольку серпентиновые минералы (хризотил и лизардит) не содержат тетраэдрического алюминия, то кремнекислородный этаж (сетка), частично унаследованая от них структура, должна состоять из одних кремнекислородных тетраэдров. Однако в случае повышения щелочности раствора часть алюминия может приобретать тетраэдрическое окружение кислорода и присоединяться к кремнекислородному этажу образующегося смектита. Трехэтажные слоистые силикаты в процессе гидротермального воздействия и выветривания претерпевают частичные изменения, вследствие которых происходит их трансформация в другие подобного же строения образования. Подтверждением этому, кроме геологических наблюдений, являются экспериментальные данные, которые свидетельствуют о том, что наиболее устойчивыми к кислотному воздействию являются кремнекислородные сетки вместе с находившимся в них тетраэдрическим алюминием, количество которого в хлоритах определяют путем кислотного выщелачивания, при котором он остается в нерастворимом остатке. То же самое можно отнести и к слюдам (особенно триоктаэдрическим). Поэтому слюды в процессе трансформации в сильно магнезиальной среде превращаются в хлориты или вермикулиты, со сбережением трехэтажного алюминий-кремниевого слоя, заряд которого зависит, главным образом, не от замещений в тетраэдрах, а в октаэдрических позициях. В связи с этим, при изменении среды из кислой на вызванную обычно изобилием в растворе кальция нейтральную или слабощелочную деградированные слюды, вермикулит, а также хлориты трансформируются в сапонит, и при этом часть алюминия остается в тетраэдрическом этаже. Однако сапонит образуется не только (и не столько) за счет трансформации в него слюд или хлоритов, но также в процессе разложения туфов, плагиоклазов, различных пород, в которых имеется много тетраэдрического алюминия и магнезии. Последняя в изоби- 
лии содержится в КБ и при наличии алюмосиликатов (флогопита) из самих кимберлитов, биотита, плагиоклазов и стекла вмещающих пород в гидротермальных условиях, и в процессе выветривания при повышенном содержании кальция и натрия возникает сапонит, который может служить поисковым признаком на кимберлитовые тела.

Отмечены существенные различия в направленности и схеме преобразования КВ на терригенно-карбонатных породах нижнего палеозоя, широко развитых рядом с кимберлиитовыми диатремами и из-за обохренности верхних горизонтов трудно различающимися. Подвергшиеся выветриванию исходные породы в таких профилях представлены алевролитами и песчаниками с известково-доломитовым цементом и прослоями карбонатизированных аргиллитов. В рассматриваемых породах в нижних частях профилей выветривания довольно широким распространением пользуются преимущественно диоктаэдрические слоистые силикаты политипных модификаций $1 \mathrm{M}$ и $2 \mathrm{M}_{1}$ $\left(1 \mathrm{M}>>2 \mathrm{M}_{1}\right)$. С ними ассоциируются следующие аутигенные минералы: триоктаэдрический хлорит с небольшой примесью хлорит-монтмориллонитового смещанослойного образования (XМСО) с преобладанием неразбухающих пакетов, т.е. с тенденцией к упорядоченному чередованию их с подчиненными - разбухающими. Реликтовые минералы представлены кварцем, микроклином, санидином, альбитом, олигоклазом, пиритом и магнетитом. В средней зоне гидрослюда $1 \mathrm{M}$, как менее устойчивая фаза по сравнению с модификацией $2 \mathrm{M}_{1}$, частично переходит в монтмориллонит-гидрослюдистое смешанослойное образование (МГСО), в котором подчиненные - неразбухающие слои неупорядоченно чередуются с преобладающими - разбухающими. Полную деструкцию претерпевает хлорит, а постпиритная $\mathrm{H}_{2} \mathrm{SO}_{4}$ приводит [4-6, $21,22,25,26]$ к возникновению метастабильных фаз: ярозита, алунита, алуминита, базалюминита и гипса. В верхней зоне в кислой среде из остаточных продуктов разложения первичных минералов синтезируется каолинит. При этом, за счет трансформации МГСО, характеризующегося наименьшей стабильностью в рассматриваемой зоне, кристаллизуется каолинит 1-й генерации с полубеспорядочной структурой, наследуемой от весьма разупорядоченного минералапредшественника. Из продуктов разложения кислых плагиоклазов возникает также каолинит П генерации с относительно несовершенной структурой. По наиболее устойчивому в профиле выветривания микроклину развивается каолинит Ш генерации с более упорядоченной структурой. В результате окисления магнетита в верхнем горизонте профиля КВ образуется гематит, гётит и гидрогетит. Гидрослюда $2 \mathrm{M}_{1}$ остается сравнительно стабильной и по сравнению с реликтами гидрослюды $1 \mathrm{M}$, соотношение их претерпевает инверсию $\left(2 \mathrm{M}_{1}>1 \mathrm{M}\right)$.

Таким образом, проведенными исследованиями апробирована методика минералогического картирования отдельных горизонтов сложно построенных кимберлитовых диатрем, показавшая широкое развитие как в плане, так и на разведанную глубину, слюдистых образований. Концентрация флогопита уменьшается вверх по разрезам и в значительной мере контролируется степенью постмагматических и гипергенных преобразований пород диатрем. К верхам кимберлитовых трубок увеличивается роль хлорита, образованного за счет трансформации и изменения флогопита. На распределение слюдистых образований влияет как количество алюмосиликатов, так и интенсивность их переработки. В верхних частях диатрем за счет постмагматического и гипергенного изменения пород за счет уменьшения роли флогопита, увеличивается концентрация хлорита, что следует учитывать при проведении прогнозно-поисковых работ на алмазы на таких территориях. Анализируя результаты комплексного изучения кимберлитов СП, можно отметить несколько типов щелочности алмазоносных пород. В направлении от центра платформы в северном направлении уменьшается роль алмазоносных кимберлитов. В пределах кимберлитовых полей северной части СП щёлочные породы представлены магматитами пикритов, а ультраосновные типы кимберлитами низких уровней продуктивности, что указывает на нахождение областей образования расплавов этих пород вне зоны устойчивости алмаза. В отличие от этого, кимберлиты МБАР, СМАР и ДААР формировались в диапазоне всей области устойчивости алмазов. Проведенными исследованиями обогащенных слюдистыми образованиями пород кимберлитовых диатрем НКП показано, что в верхних их горизонтах доминируют АКБ. ПК встречается фрагментарно в виде обломочного материала, что связано с более ранним внедрением. Кимберлитовые брекчии характеризуются переменным составом вкрапленников и связующей матрицы, что отражается на цветовой гамме самих пород и их физико-механических свойствах. Ксенолиты в кимберлитах НКП представлены преимущественно обломками вмещающей терригенно-карбонатной толщи, реже отмечаются обломки метаморфических и мантийных пород. Распределение ксенолитов в диатремах неравномерное, максимальное их количество приурочено к приконтактовым частям трубок при незначительном увеличении содержания с глубиной. Для пород трубок характерно низкое содержание минералов тяжелой фракции, среди которых доминируют гранаты и аутигенные пирит и гидроокислы железа; в меньшей мере встречаются магнетит, пикроильменит, хромит и хромдиопсид. По химическим данным исследуемые породы из диатрем СП принадлежат одному петрохимическому типу кимберлитов, а установленные вариации концентраций петрогенных оксидов связаны с разной интенсивностью протекания постмагматических и гипергенных процессов на разных глубинах месторождения.

Зафиксированные неоднородности в геохимическом поле обусловлены степенью вторичного изменения пород, а также спецификой формирования и становления трубки. В постмагматическую и гиперген- 
ную стадии произошло существенное изменение кимберлитов с широким (до 90 \%) развитием минераловновообразований, среди которых преобладают серпентин, карбонаты, флогопит и продукты его изменения - хлорит. Вторичные минералы существенно влияют на изменение физико-механических свойств кимберлитов, что отражается на устойчивости качественно-количественных параметров алмазного сырья. Проведенный корреляционный анализ распределения вторичных минералов с потенциальной алмазоносностью кимберлитов показал обратную зависимость содержания слюды, кварца и доломита с концентрацией полезного компонента в изученных месторождениях.

Характерными особенностями алмазов из кимберлитов изученных диатрем является доминирование прозрачных (или полупрозрачных) индивидов октаэдрического и переходного от октаэдрического к ромбододекаэдрическому габитусов 1 разновидности, при заметном содержании алмазов с оболочкой $1 У$ разновидности. Отмечено преобладание однородных кристаллов с розово-сиреневым свечением и двухзонным внутренним строением. В кристаллах алмаза отмечена связь примеси азота с кристалломорфологией, причем наиболее обогащенны этой примесью плоскогранные октаэдры, что приводит к их хрупкости и сравнительно легкому растрескиванию на разнообразные осколки.

Отмеченная в результате проведенных исследований последовательность изменения минералогических ассоциаций вверх по разрезам профилей выветривания кимберлитов во многом определяются открытой системой минералообразования. Оптимальный для них диапазон изменения среды обычно располагается при $\mathrm{pH}$ от слабощелочной до слабокислой. В слабощелочных условиях, наиболее типичных для затронутых гипергенными процессами (особенно ультраосновных кимберлитов), возникают алюмосиликаты, в которых $\mathrm{Al}$, подобно $\mathrm{Si}$, образует тетраэдры $\mathrm{AlO}_{4}$ (сапонит, вермикулит, хлорит, ди-, три- и диоктаэдрические смешанослойные образования). В отличие от этого в нейтральной и слабокислой среде синтезируются силикаты и алюмосиликаты с преобладанием в структуре октаэдрического Al (каолинит, мета- и гидрогаллуазит). При этом $\mathrm{pH}$ в условиях углекислотного выветривания снижается с 8 в нижних горизонтах до 4, а сернокислотного - до 1,5-2,5. Различный механизм изменения неслоистых и слоистых минералов в процессе выветривания открывает возможность (в дополнение к дифференциации пород по степени их силификации) отдельно выделять и исследовать среди главнейших двух групп пород (т.е. ультраосновных и основных, с одной стороны, и средних и кислых - с другой) также такие важные их разности, как бесслюдистые и слюдистые. Развитие в средних частях профилей выветривания бесслюдистых пород смектитов, а в аналогичных горизонтах слюдистых также и смешанослойных образований (особенно монтмориллонит-гидрослюдистого типа), позволяет надежно идентифицировать тип исходных пород не только в элювии, но и в осадочных толщах, обогащенных продук- тами размыва выветрелого материала. Значительную помощь в этом может оказать оценка степени упорядоченности гипергенных минералов, унаследованная от структур гипогенных фаз. Аналогичный механизм преобразования исходных пород в КВ в течение геологической истории Земли в неогее показывает, что происходящие при этом процессы имеют универсальный характер и не зависят ни от возраста образовавшегося элювия, ни от положения выветрелого материала при близком типе пород в различных регионах.

\section{ЛИТЕРАТУРА}

1. Закономерности изменения мантийных минералов в коре выветривания кимберлитов / В. П. Афанасьев [и др.] // Сб.: Минерагения зоны гипергенеза. - М.: Наука. 1980. - С.45-54. 2. Петрография и минералогия кимберлитовых пород Якутии / А. П. Бобриевич [и др.] - М.: Недра. 1964. - 190 с.

3. Василенко, В.Б. Петрохимические модели алмазных месторождений Якутии / В. Б. Василенко, Н. Н. Зинчук, Л. Г. Кузнецова - Новосибирск: Наука.1997. - 557 с.

4. Зинчук, Н. Н. Постмагматические минералы кимберлитов / Н. Н. Зинчук - М. : Недра. 2000. - 538 с.

5. Зинчук, Н. Н. Типоморфизм алмазов Сибирской платформы / Н.Н.Зинчук, В.И.Коптиль - М. : Недра. 2003. - 607 с.

6. Особенности слоистых силикатов из кимберлитов и вмещающих их пород в зонах активного воздействия траппового магматизма (на примере Якутии) / Н. Н. Зинчук [и др.] // Докл. АН СССР. - 1989. - Т.305. - №5. - С.11991202.

7. Кимберлитовая трубка Удачная (вещественный состав и условия формирования) / Н. Н. Зинчук [и др.] - Новосибирск: НГУ.1993. - 147 с.

8. Флогопит и продукты его изменения в кимберлитовых породах Якутии / Н. Н. Зинчук, [и др.] // Сб.: Минералы и парагенезисы минералов горных пород и руд. Л. : Наука. 1979. - C.69-76.

9. Вторичные минералы кимберлитов / Н. Н. Зинчук [и др.] - Киев: Наукова думка. 1987. - 282 с.

10. Маршинщев, В. К. Вертикальная неоднородность кимберлитовых тел Якутии / В. К. Маршинцев - Новосибирск: Наука. 1986. - 239 с.

11. Рожков, И. С. Древняя кора выветривания кимберлитов трубки имени ХХШ сьезда КПСС (Якутия) / И. С. Рожков, А. Д. Харькив, Ю. М. Мельник // Докл. АН СССР. - 1969. Т.188. - №5. - С. 1130-1135.

12. Соболева, С. В. Политипия слюд: теоретический и прикладной аспекты / С. В. Соболева // Минералогический журнал. - 1987. - №-4. - С.26-41.

13. Особенности флогопита мантийного происхождения / С. В. Соболева [и др.] // Записки ВМО. - 1979. - Ч.108. Вып.6. - С.678-685.

14. Харькив, А. Д. Коренные месторождения алмазов Мира / А. Д. Харькив, Н. Н. Зинчук, А. И. Крючков - М. : Недра. 1998. - $555 \mathrm{c}$.

15. Хитров, В. Г. Применение кластер-анализа для выяснения закономерностей выветривания пород различного состава / В. Г. Хитров, Н. Н. Зинчук, Д. Д. Котельников // ДАН СССР. - 1987. - Т. - 296. - №5. - С.1228-1233.

16. Зинчук, Н. Н. Кимберлиты в истории Земли. Методическое пособие / Н. Н. Зинчук, А. Д. Савко, А. В. Крайнов // Труды НИИГ ВГУ. - Вып.68. - Воронеж: ВГУ. - 2013. - 99 с. 17. Савко, А. Д. О соотношении мощного корообразования и кимберлитового магматизма в истории Земли / А. Д. Савко, Л. Т. Шевырев, Н. Н. Зинчук // Вестник Воронеж. гос. 
ун-та. Сер.: Геология. - 1997. - №3. - С.3-24.

18. Савко, А. Д. Ассоциации минералов-индикаторов алмазоносности в осадочном чехле Воронежской антеклизы / А. Д. Савко, Л. Т. Шевырев, В. В. Ильяш // Проблемы алмазной геологии и некоторые пути их решения .- 2001 .C. $423-433$.

19. Никулин, И.И. Литология алмазоносных нижнеюрских отложений Накынского кимберлитового поля (Западная Якутия) / И. И. Никулин, А. Д. Савко // Труды НИИГ Воронеж. гос. ун-та. - Вып. 56. - Воронеж: ВГУ. - 2009. - 133 с. 20. Зинчук, Н. Н. Историко-минерагенический анализ коренной алмазоносности Сибирской платформы / Н. Н. Зинчук, А. Д. Савко, Л. Т. Шевырев // Труды НИИГ Воронеж. гос. ун-та. - Вып. 61. - Воронеж: ВГУ. - 2010. - 100 с.

21. Зинчук, Н. Н. Особенности минерагении древних платформ / Н. Н. Зинчук, А. Д. Савко, Л. Т. Шевырев // Сб. Комплексное изучение и освоение природных и техногенных россыпей. Труды 4-й Международной научнопрактической конференции.-Симферополь: КО УкрГГРИ. 2008. - C.42-52.

Западно-Якутский научный центр (ЗЯНЦ) АН Республики Саха (Якутия), Мирный

Зинчук Николай Николаевич, председатель, д. г.-м. н., профессор, академик АН РС (Я), заслуженный деятель науки РС (Я), заслуженный геолог РФ

E-mail: nnzinchuk@ rambler.ru

Тел.: 8-980-663-01-86
22. Зинчук, Н. Н. Геолого-вещественные особенности кимберлитовых диатрем / Н. Н. Зинчук // Вестник Пермского ун-та. Геология. - 2016. - №4 (33). - С.70-89.

23. Результаты исследований слоистых силикатов интенсивно измененных кимберлитов и тонкодисперсных фракций их преобразований / Г. П. Двойченко [и др.] // Отечественная геология. - 2016. - С.219-221.

24. Зинчук, Н. Н. Особенности серпентинизации кимберлитовых пород / Н. Н. Зинчук // Вестник Воронеж. гос. ун-та. Сер.: Геология. - 2017. - №3. - С.66-74.

25. Зинчук, Н. Н. Особенности глинистых минералов в древних корах выветривания различных пород в алмазоносных регионах / Н. Н. Зинчук // Сб.: Проблемы минералогии, петрографии и металлогении. Научные чтения памяти П. Н. Чирвинского. - Вып.18.-Пермь: Перм. национальный исследовательский ун-т. - 2015. - С.154-166.

26. Савко, А. Д. Эпохи мощного корообразования и алмазоносного магматизма в истории Земли / А. Д. Савко, Л. Т. Шевырев, Н. Н. Зинчук // Воронеж : Воронеж. гос. ун-т, 1999. - $102 \mathrm{c}$.

West Yakut scientific center (WYSC) AS Republic of Sakha (Yakutia), Mirny

Zinchuk N. N., Chairman, doctor of the Mineralogical and Geological Sciences, Professor, Academician of Academy of Science $R S(Y)$, honored worker of science RS $(Y)$, selebrated Geologist of Russia

E-mail: nnzinchuk@rambler.ru; Tel.: 8-980-663-01-86 